Research

\title{
Proton pump inhibitors effect on the quality of life of patients with laryngopharyngeal reflux
}

\author{
Susyana Tamin*, Elvie Zulka*, Rahmanofa Yunizaf*, Adang Bachtiar** \\ * Department of Otorhinolaryngology Head and Neck Surgery, Faculty of Medicine, \\ Universitas Indonesia Dr. Cipto Mangunkusumo Hospital, Jakarta \\ **Department of Health Policy and Administration, Faculty of Public Health, \\ Universitas Indonesia, Jakarta
}

\begin{abstract}
Background: Laryngopharyngeal reflux (LPR) is a condition caused by retrograde flow of gastric contents to the larynx, pharynx, trachea, and bronchus, which can affect patients' quality of life (QOL). Purpose: To evaluate the effect of proton pump-inhibitor (PPI) therapy on the quality of life of patients with laryngopharyngeal reflux (LPR). Methods: This randomized controlled trial study involved 52 patients with dysphagia. The short-form REFLUX-QUAL ${ }^{\circledR}$ questionnaire was used to assess QOL. The patients were given lansoprazole twice daily as early diagnostic method as well as a therapy for LPR. If improvement found, PPI therapy was continued for two months. Afterwards patients was randomly divided into continuous therapy group $(n=25)$ or an on-demand therapy group $(n=27)$. Results: There was no significant difference in gender, age group, or economic level among subjects in both groups. Treatment with PPIs both continuously and on-demand significantly improved patients' QOL from 44.83 \pm 19.11 to $83.37 \pm 11.51(\mathrm{p}<0.001)$. Significant improvements occurred in almost all of eight QOL domains as compared at the start of and six months into PPI therapy $(\mathrm{p}<0.001)$; discomfort remained the exception as patients with LPR must continue to avoid certain foods, $(p=0.233)$. However, there was no significant difference between the continuous and on-demand therapy groups concerning improvements in the quality of life $(p=0.281)$. Conclusion: Treatment with PPIs either continuously or on-demand for six months significantly improved patients' quality of life, with no significant difference between the two treatment groups.
\end{abstract}

Keywords: proton pump inhibitor, PPI, quality of life, laryngopharyngeal reflux, LPR

\begin{abstract}
ABSTRAK
Latar belakang: Refluks laringofaring (RLF) adalah kondisi terjadinya aliran balik isi lambung ke laring, faring, trakea, dan bronkus yang dapat mempengaruhi kualitas hidup pasien. Terapi empiris Proton Pump Inhibitor (PPI) merupakan pendekatan diagnosis dan metode terapi untuk RLF. Tujuan: Penelitian ini bertujuan untuk mengevaluasi efektivitas pengobatan PPI terhadap kualitas hidup pasien RLF Metode: Penelitian secara uji acak terkendali ini melibatkan 52 pasien dengan keluhan disfagia. Digunakan Reflux-Qual Short form (RQS) untuk menilai kualitas hidup subjek. Pasien diberikan lansoprazole dua kali sehari sebagai diagnosis dini dan terapi untuk refluks. Apabila terdapat perbaikan, PPI diteruskan selama 2 bulan, kemudian pasien dibagi menjadi 2 grup secara acak. Kelompok pasien yang mendapatkan terapi secara kontinu terdiri dari 25 pasien, sedangkan kelompok terapi on-demand terdiri dari 27 pasien. Hasil: Tidak terdapat perbedaan signifikan pada jenis kelamin, usia, tingkat ekonomi antara pasien pada kelompok terapi kontinu dan on-demand. Pengobatan PPI secara kontinu dan on-demand secara signifikan meningkatkan kualitas hidup pasien dari 44,83 $\pm 19,11$ menjadi 83,37 $\pm 11,51(p<0,001)$. Selain itu, terdapat perbaikan yang signifikan pada hampir semua dari delapan domain kualitas hidup pada bulan keenam terapi PPI dibandingk an awal terapi, kecuali pada domain ketidaknyamanan pasien karena pasien harus menghindari makanan tertentu $(p=0,233)$. Namun, tidak ditemukan perbedaan yang signifikan pada kelompok terapi secara kontinu dan on-demand pada
\end{abstract}


peningkatan kualitas hidup ( $p=0,281)$. Kesimpulan: Pengobatan PPI secara kontinu dan on-demand selama 6 bulan secara signifikan meningkatkan kualitas hidup pasien RLF. Namun, tidak ada perbedaan yang signifikan antara kedua kelompok tersebut terhadap peningkatan kualitas hidup.

Kata kunci: penghambat pompa proton, PPI, refluks laringfaring, refleks laringofaring, kualitas hidup

Correspondence address: Susyana Tamin, Department of Otorhinolaryngology Head and Neck Surgery, Faculty of Medicine, Universitas Indonesia-Cipto Mangunkusumo Hospital. Jl. Diponegoro No. 71, Jakarta 10430, Indonesia. Email: usyana@yahoo.com

\section{INTRODUCTION}

Laryngopharyngeal reflux (LPR) is a condition that results from irritation caused by retrograde flow of gastric contents into the larynx, pharynx, trachea, and bronchus. LPR patients may present with diverse symptoms, including throat-clearing, dysphonia, globus sensation, postnasal drip, dysphagia, and dry cough. ${ }^{1-3}$ Chronic cough and voice disorder are the main complaints associated with LPR in more than $50 \%$ of affected patients. Furthermore, patients with LPR are reported to experience more discomfort in their daily life relative to patients with other conditions. ${ }^{4}$

To assess the presence and symptoms of LPR, Belafsky et al. established the Reflux Symptom Index (RSI) and the Reflux Finding Score (RFS). ${ }^{3,5,6}$ First, the RSI is an easy self-administered outcomes instrument consisting of nine items, with a maximum total score ranging from zero to 45 points. An RSI score of greater than 13 points suggests LPR. ${ }^{5}$ Separately, the RFS is a scoring system used to identify LPR based on fiberoptic laryngoscopy findings that consist of eight items involving the most common laryngoscopic results in LPR patients, such as excess mucus in the larynx, granulation tissue, posterior commissure hypertrophy, subglottic edema, vocal fold edema, ventricular obliteration, generalized laryngeal edema, and erythema. A total score of 26 points based on the scoring of each item according to the presence or absence, location, and severity of the characteristic is possible, and patients with a total score of seven points or higher are considered to have LPR. ${ }^{6-8}$

LPR is a common disorder and may be found in up to $10 \%$ of patients who visit otorhinolaryngologists. ${ }^{9}$ LPR can significantly affect patients' social functioning, psychological status, and quality of life (QOL). Also, laryngopharyngeal reflux disease (LPRD) negatively influences the QOL in the areas of physical and emotional functioning. ${ }^{4,10}$ The main complaints made by patients with LPRD concern voice problems, chronic coughing, frequent phlegm discharge, and frequent globus sensations that trigger problems in social and work environments in the form of psychological, emotional, and social issues. ${ }^{4,11}$ Hence, the impact of proton pump inhibitors (PPIs) on patients' QOL is an essential consideration during treatment. ${ }^{4,12}$

The assessment of QOL is mostly done using now-standard health-related QOL assessments, such as the short-form Nottingham Health Profile (SF-36) and the Psychological General Well-being Index. ${ }^{11-13}$ The SF-36 contains eight domains, including physical functions, physical limitations, social functions, pain, vitality, mental health, general health perceptions, and emotional limitations, to describe patients' overall health. ${ }^{11,12}$

Both Lenderking et al. ${ }^{11}$ and Carrau et al. ${ }^{12}$ used the SF-36 to look at the effect of LPRD as compared with that of gastroesophageal reflux disease (GERD) on the QOL of 
patients. Carrau et al. ${ }^{12}$ found that LPRD patients differed significantly from GERD patients in terms of their social functioning and vitality. One weakness of the SF-36, however, is that it only describes the overall health of the patient. ${ }^{12,13}$ Amouretti et al. ${ }^{14}$ developed an instrument for assessing the QOL specifically in GERD patients called the short-form REFLUX-QUAL $®$ (RQS), which is a short and reliable means to evaluate the QOL with good validity and reliability values and with sensitivity to both intra- and intersubject differences.

Empirical therapy using PPIs for LPRD and GERD has been widely accepted as both a diagnostic approach and treatment method. ${ }^{10,12}$ Besides being noninvasive and simple, this technique can also provide rational and reasonable value for the patients. Various types of PPIs are available and studies have been carried out using various doses and durations. ${ }^{15,16}$ Common PPI regimens in the form of $30 \mathrm{mg}$ lansoprazole twice daily or 20 mg of omeprazole twice daily. ${ }^{17}$ Systematic reviews of various studies had also suggested other PPIs such as rabeprazole (20 mg twice daily), pantoprazole (40 mg twice daily), or esomeprazole (40 mg twice daily). ${ }^{18,19}$

For medical therapy in patients with symptomatic LPR, maintenance therapy can be given continuously, usually twice daily, as determined by the doctor. However, other therapeutic schedules also exist, such as intermittent therapy or alternate therapy, which are also determined by the doctor, and on-demand therapy, which is entirely determined by the patient. Many patients prefer on-demand therapy as it allows them to decide when they need therapy, helping them to feel in control of their treatment.

This study aims to ascertain the treatment response to PPIs when given continuously or on-demand by assessing the QOL of LPR patients.

\section{MATERIALS AND METHODS}

This study included 93 patients with dysphagia who visited the Dysphagia Clinic (Faculty of Medicine Universitas Indonesia/National Reference Hospital of Indonesia dr Cipto Mangunkusumo Hospital). Eligible patients underwent anamnesis; RSI scoring; a general ear, nose, and throat assessment; a QOL evaluation; and a fiberoptic nasopharyngolaryngoscopy examination. The RQS was used to assess the QOL of the 93 patients; however, 29 patients were not randomized because they did not show up after the PPI therapy trial. Of the 64 patients who participated, seven were lost to follow-up in the fourth month and five were lost to follow-up in the sixth month, respectively, resulting in just 52 patients remained observed until the end of the study. Of these participants, 25 received continuous therapy and 27 received on-demand therapy.

Patients with dysphagia co-presenting with any other obvious cause for such symptoms, such as a history of hypopharynx malignancies; patients with dysphagia and neurological abnormalities; patients with a history of alcohol consumption; LPRD patients under current treatment; and patients who had previously undergone an operation on the larynx were excluded from this study.

Patients were treated using $30 \mathrm{mg}$ of lansoprazole twice daily as an early diagnostic method and as a therapy for reflux. Following any improvements in symptoms, the RQS was applied to evaluate the QOL before the patients began using PPI therapy. PPI treatment continued for two months; then, each patient was randomly placed into one of two groups, either an on-demand treatment group or a continuous treatment group. The on-demand group was given $30 \mathrm{mg}$ of lansoprazole twice daily only when they had a complaint, and the duration of treatment was self-determined by the patients, while the continuous group was given $30 \mathrm{mg}$ of lansoprazole twice daily continuously. 
Patients were expected to visit the clinic every two weeks during and after the use of PPI therapy for six months. RSI and RFS assessments were conducted using flexible fiberoptic nasopharyngolaryngoscopy, while evaluations of the QOL were performed using the RQS.

Data analysis was implemented using the Statistical Package for the Social Sciences version 20.0 software program (IBM Corporation, Armonk, NY, USA). Methods of analysis included univariate for descriptive analysis and bivariate using the analysis of variance test to evaluate the difference between the effects of continuous and ondemand PPI therapy on patients' QOL

\section{RESULTS}

Fifty-two patients completed the study, including 27 in the on-demand group and 25 in the continuous group. Seventeen patients $(32.7 \%)$ were male and 35 patients $(67.3 \%)$ were female. Patients aged 40 to 69 years $(59.6 \%)$ were more numerous than those aged 20 to 39 years $(40.4 \%)$. The majority of patients $(55.7 \%)$ came from a moderate economic level, followed by those from a high economic level (25\%) and a lower economic level $(19.3 \%)$. There was no significant difference in patient gender, age group, or economic level among individuals between the continuous and on-demand groups.

Table 1. Disturbance in QOL in Each Domain

\begin{tabular}{lc}
\hline Domain & $\%$ \\
\hline Role limitations, emotional (anxiety due to throat problems) & 89.5 \\
Mental health (unsatisfied with the expected outcome) & 81.4 \\
Physical function (work disruption due to symptoms) & 74.4 \\
Role limitations, physical (work limitations due to symptoms) & 62.7 \\
Vitality (waking up in the middle of the night) & 54.7 \\
Bodily pain (avoidance of certain foods) & 54.7 \\
Social function (temperamental) & 52.3 \\
General health perceptions (good appetite) & 41.9 \\
\hline
\end{tabular}

Table 2. QOL score alterations between before and after PPI therapy

\begin{tabular}{lcccc}
\hline QOL Domain & post $<$ pre (n) & post $>$ pre (n) & post = pre (n) & p-value \\
\hline Physical function & 4 & 41 & 7 & $<0.001$ \\
Role limitations, physical & 3 & 33 & 16 & $<0.001$ \\
Mental health & 2 & 41 & 9 & $<0.001$ \\
General health perception & 4 & 29 & 19 & $<0.001$ \\
Role limitations, emotional & 0 & 45 & 7 & $<0.001$ \\
Social function & 2 & 34 & 16 & $<0.001$ \\
Vitality & 2 & 33 & 17 & $<0.001$ \\
Bodily pain & 12 & 24 & 16 & 0.233 \\
\hline
\end{tabular}

In Table 1, it could be seen that, among the eight QOL domains, most patients' complaints fit into the emotional role limitations (89.5\%), mental health $(81.4 \%)$, physical function $(74.4 \%)$, and physical role limitations $(62.7 \%)$ categories, respectively.
Table 2 showed that significant improvements occurred in almost all of the eight QOL domains from the beginning of PPI therapy to six months after PPI therapy $(p<0.001)$. However, there were no statistically significant changes in discomfort 
because patients must avoid certain foods ( $p$ $=0.233$ ) both at the beginning of therapy and six months post treatment. It could also be seen from Table 2 that the provision of PPI for six months triggered real improvement, especially in the domains of emotional role limitations ( $\mathrm{n}=45 / 52$ patients; $86.5 \%)$, physical function ( $\mathrm{n}=41 / 52$ patients; $78.8 \%)$, and mental health $(\mathrm{n}=41 / 52$ patients; $78.8 \%)$.
Treatment with PPIs both continuously and on-demand significantly improved patients' QOL from $44.83 \pm 19.11$ to 83.37 $\pm 11.51(\mathrm{p}<0.001)$. However, there was no significant difference between the continuous and on-demand groups in terms of improvements in the QOL $(\mathrm{p}=0.281)$.

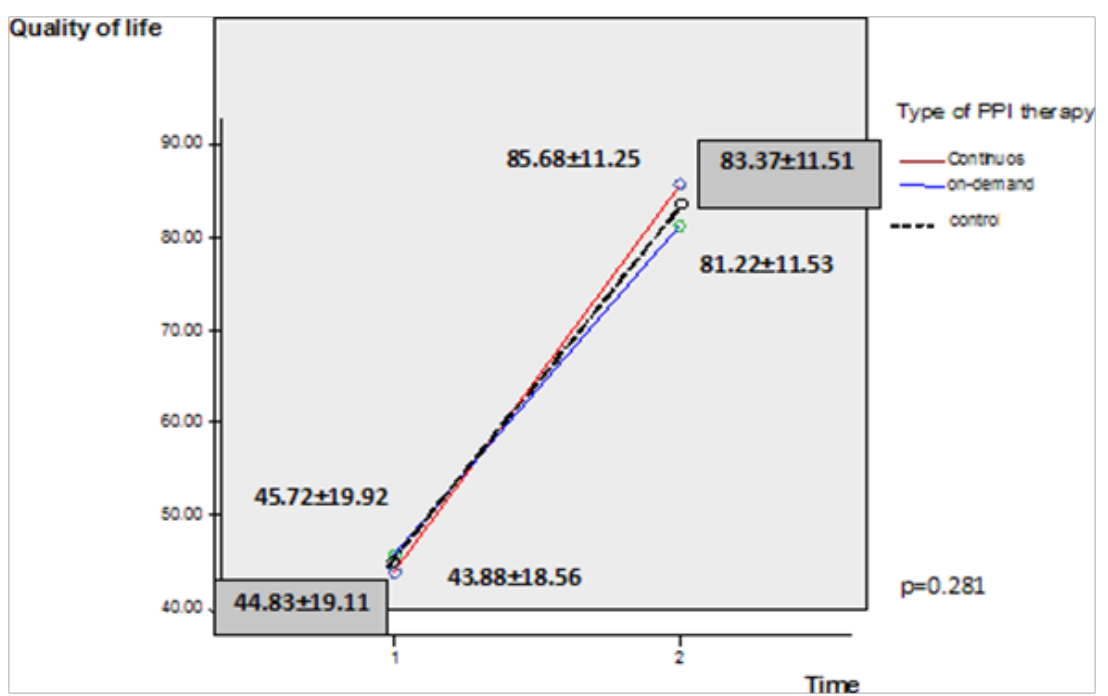

Figure 1. Comparison of the initial QOL scores with those recorded at six months post therapy in the continuous and on-demand therapy groups

\section{DISCUSSION}

LPR is one extraesophageal manifestation of GERD that leads to various symptoms that may affect patients' daily activity. GERD is a common clinical problem with an adverse impact on QOL. A greater symptoms burden has been correlated with a significant decrease in the health-related QOL. GERD patients with LPR symptoms have poorer QOL scores as compared with GERD patients without LPR symptoms. In addition, a reduction in the health-related QOL has been associated with persistent or recurrent symptoms. ${ }^{10}$

Our study results revealed a significant change in QOL occurred from before PPI therapy to six months after therapy, increasing from $44.83 \pm 19.11$ to $83.37 \pm 11.51(\mathrm{p}<$ 0.001). Moreover, both continuous and on- demand therapy improved the QOL in a manner that was not significantly different between before and six months after treatment $(\mathrm{p}=0.281)$.

Out of the eight items covered in the assessment of QOL, seven items - namely, physical function, role limitation physical, emotional, mental health, general health, social functioning and vitality - demonstrated significant improvements between before and after therapy $(p<0.001)$. Only the eighth item, interpreted as abstinence from food, was not significantly changed $(p=0.233)$.

This study showed that the presence of LPRD and lingual tonsillar hypertrophy altered the QOL of patients, affecting both physical and mental components. Patients' QOL was mainly affected in the 
domains of emotional limitations (89.5\%) and mental health disorders $(81.4 \%)$, with the latter appearing in the form of anxiety and dissatisfaction with recovery. Following the provision of PPIs for six months, it could be seen in this study that there was a significant difference between at the beginning of therapy and at six months post treatment in almost all QOL domains, except for the discomfort that occurred due to the need to keep avoiding certain foods. PPI provision for six months provided a real improvement, especially in the domains of emotional limitations $(86.5 \%$ of patients), physical function (78.8\%), and mental health $(78.8 \%)$.

In general, LPR, which is a manifestation of acid reflux, is characterized by symptoms of dysphagia, excessive phlegm that causes persistent throat clearing, globus sensation, chronic coughing, laryngospasm, and hoarseness. ${ }^{10,12}$ However, most LPR patients do not have classic GERD symptoms such as regurgitation and heartburn, ${ }^{10,11} \mathrm{LPR}$ still significantly and negatively influences patients' lives. Patients clinically diagnosed with LPR have worse Voice Handicapped Index scores than GERD patients without LPR. ${ }^{20}$ Siupsinskiene et al. ${ }^{21}$ found that more than $77 \%$ of LPR patients experienced a significant decrease in social activity and an increase in psychological disorders, with more anxious conditions diagnosed in LPR patients as compared with healthy controls.

Lenderking et al. ${ }^{11}$ and Carrau et al. ${ }^{12}$ both used the SF-36 to stratify the effects of LPRD and GERD on patients' QOL. Carrau et al. ${ }^{12}$ reported that LRPD patients had lower QOL values and differed significantly from GERD patients in terms of social function and vitality, while in five of the six other domains, LPR patients presented lower values but not significantly so. ${ }^{12}$ Lenderking et al. ${ }^{11}$ found that LPRD had a negative influence on QOL in terms of both physical and emotional functioning. The main complaints affecting LPRD patients include voice problems, recurrent chronic cough the frequent throat clearing, globus sensations, and swallowing disorders, which often cause problems in social and work environments in the form of psychological, emotional, and social problems.

Social and occupational factors have greater influence on patients who have voice complaints than others. ${ }^{11}$ The quality of the voice is widely esteemed in certain social and work environments. The extra-esophageal symptoms of reflux, such as coughing, voice problems, and throat clearing, affect the individual with high voice quality demand, namely singer, chorister, and teacher, to seek medical help. ${ }^{22}$ In addition, the development of hoarseness and benign lesions of vocal folds in LPR decrease communication and interaction effectiveness. ${ }^{23}$ Because so much work requires verbal interaction, the influence of voice problems can reduce the social function, which is one domain considered when assessing the QOL. ${ }^{11}$

The influence of psychological factors must also be considered. One-third of LPR patients have anxiety and a significant reduction in social activities. ${ }^{24}$ Patients with LPR have a significant increase in anxiety scores with Hospital Anxiety and Depression Scale (HADS). Patients might have anxiety over significant pathology, chronic nature of the disease, and lumps in their throat and are concerned about this symptom, whether it is an early sign of malignancy. ${ }^{11,25}$ This adds to the anxiety, negatively affecting the patients' psychological, emotional, and social functions. There is also an influence on selfconfidence and relationships. Fatigue and frustration generally increase stress levels, which can reduce patients' QOL. ${ }^{11}$

In conclusion, treatment with PPIs both continuously and on-demand for six months significantly improved patients' QOL. No significant difference was observed between the treatment groups concerning the improvement in QOL. 


\section{ACKNOWLEDGMENTS}

We would like to thank the Department of Otorhinolaryngology-Head and Neck Surgery, Faculty of Medicine, Universitas Indonesia; the Division of Gastroenterohepatology, Department of Internal Medicine, Faculty of Medicine, Universitas Indonesia; and the Department of Health Policy and Administration, Faculty of Public Health, Universitas Indonesia for supporting this study.

\section{CONFLICTS OF INTEREST}

The authors declare that no conflicts of interest exist in this study.

\section{REFERENCE}

1. Chiba T. Laryngopharyngeal reflux disease (LPRD)-review article. Med Res Arch 2017;5(2):14

2. Lee YC, Lee JS, Kim SW, Kwon KH, Eun YG. Influence of age on treatment with proton pump inhibitors in patients with laryngopharyngeal reflux disease: a prospective multicenter study. JAMA Otolaryngol Head Neck Surg. 2013;139(12):1291-5.

3. Nunes HS, Pinto JA, Zavanela AR, Cavallini AF, Freitas GS, Garcia FE. Comparison between the Reflux Finding Score and the Reflux Symptom Index in the Practice of Otorhinolaryngology. Int Arch Otorhinolaryngol. 2016;20(3):218-21.

4. Lee JS, Lee YC, Kim SW, Kwon KH, Eun YG. Changes in the quality of life of patients with laryngopharyngeal reflux after treatment. J Voice. 2014;28(4):487-91.

5. Belafsky PC, Postma GN, Koufman JA. The validity and reliability of the reflux symptom index (RSI). J Voice 2002;16:274-7.

6. Belafsky PC, Postma GN, Koufman JA. The validity and reliability of the reflux finding score (RFS). Laryngoscope 2001;111:1313-7

7. Weitzendorfer M, Antoniou SA, Schredl P, Witzel K, Weitzendorfer IC, Majerus A, et al. Pepsin and oropharyngeal $\mathrm{pH}$ monitoring to diagnose patients with laryngopharyngeal reflux. Laryngoscope. 2020;130(7):1780-6.

8. Campagnolo AM, Priston J, Thoen RH, Medeiros T, Assunção AR. Laryngopharyngeal reflux: diagnosis, treatment, and latest research. Int Arch Otorhinolaryngol. 2014;18(2):184-91.

9. Patel D, Blanco M, Vaezi M. Laryngopharyngeal Reflux and Functional Laryngeal Disorder: Perspective and Common Practice of the General Gastroenterologist. Gastroenterology \& hepatology. 2018;14:512-20.

10. Gong EJ, Choi KD, Jung HK, Youn YH, Min $\mathrm{BH}$, Song KH, et al. Quality of life, patient satisfaction, and disease burden in patients with gastroesophageal reflux disease with or without laryngopharyngeal reflux symptoms. J Gastroenterol Hepatol. 2017;32(7):133640.

11. Lenderking WR, Hillson E, Crawley JA, Moore D, Berzon R, Pashos CL. The clinical characteristics and impact of laryngopharyngeal reflux disease on health-related quality of life. Value Health. 2003;6(5):560-5.

12. Carrau RL, Khidr A, Crawley JA, Hillson EM, Davis JK, Pashos CL. The impact of laryngopharyngeal reflux on patientreported quality of life. Laryngoscope. 2004;114(4):670-4.

13. Tofangchiha S, Razjouyan H, NasseriMoghaddam S. Quality Of Life in Reflux and Dyspepsia (QOLRAD) Questionnaire in Iranian Patients with GERD: A Validation Study. Middle East J Dig Dis. 2010;2(2):8490.

14. Amouretti M, Nalet B, Robaszkiewicz M, Wainsten JP, de la Loge C, Benmedjahed K, et al. Validation of the short-form REFLUXQUAL (RQS), a gastro-esophageal reflux disease (GERD) specific quality of life questionnaire. Gastroenterol Clin Biol. 2005;29(8-9):793-801.

15. Lechien JR, Mouawad F, Barillari MR, Nacci A, Khoddami SM, Enver N, et al. Treatment of laryngopharyngeal reflux disease: A systematic review. World J Clin Cases. 2019;7(19):2995-3011.

16. Sen P, Georgalas C, Bhattacharyya AK. A systematic review of the role of proton pump 
inhibitors for symptoms of laryngopharyngeal reflux. Clin Otolaryngol. 2006;31(1):20-4.

17. Yang Y, Wu H, Zhou J. Efficacy of acid suppression therapy in gastroesophageal reflux disease-related chronic laryngitis. Medicine (Baltimore). 2016;95(40):e4868.

18. Karkos PD, Wilson JA. Empiric treatment of laryngopharyngeal reflux with proton pump inhibitors: a systematic review. Laryngoscope. 2006;116(1):144-8.

19. Wei C. A meta-analysis for the role of proton pump inhibitor therapy in patients with laryngopharyngeal reflux. Eur Arch Otorhinolaryngol. 2016;273(11):3795-801.

20. Powitzky ES, Khaitan L, Garrett CG, Richards WO, Courey M. Symptoms, quality of life, videolaryngoscopy, and twenty-fourhour triple-probe $\mathrm{pH}$ monitoring in patients with typical and extraesophageal reflux. Ann Otol Rhinol Laryngol. 2003;112(10):859-65.

21. Siupsinskiene N, Adamonis K, Toohill RJ. Quality of life in laryngopharyngeal reflux patients. Laryngoscope. 2007;117(3):480-4.

22. Hočevar-Boltežar I, Šereg-Bahar M, Kravos A, Mumović G, Mitrović S. Is an occupation with vocal load a risk factor for laryngopharyngeal reflux: a prospective, multicentre, multivariate comparative study. Clin Otolaryngol. 2012;37(5):362-8.

23. Lechien JR, Schindler A, Robotti C, Lejeune L, Finck C. Laryngopharyngeal reflux disease in singers: Pathophysiology, clinical findings and perspectives of a new patient-reported outcome instrument. European Annals of Otorhinolaryngology, Head and Neck Diseases. 2019;136(3, Supplement):S39-S43.

24. Joo Y-H, Song Y-S, Pae C-U. Relationship between Depression and Laryngopharyngeal Reflux. Psychiatry Investig. 2017;14(2):2269.

25. Cheung TK, Lam PK, Wei WI, Wong WM, $\mathrm{Ng}$ ML, Gu Q, et al. Quality of life in patients with laryngopharyngeal reflux. Digestion. 2009;79(1):52-7. 